\title{
Subjectivities, Diversity, and Interculturality in the Mexican and Colombian Education System
}

\author{
Adriana Carolina Torres Escobar
}

Faculty of Education, Universidad Santo Tomás, Bogotá, 110111, Colombia

Received December 8, 2020; Revised December 28, 2020; Accepted January 28, 2021

\section{Cite This Paper in the following Citation Styles}

(a): [1] Adriana Carolina Torres Escobar, "Subjectivities, Diversity, and Interculturality in the Mexican and Colombian Education System," Universal Journal of Educational Research, Vol. 9, No. 1, pp. 208 - 221, 2021. DOI: 10.13189/ujer.2021.090123.

(b): Adriana Carolina Torres Escobar (2021). Subjectivities, Diversity, and Interculturality in the Mexican and Colombian Education System. Universal Journal of Educational Research, 9(1), 208 - 221. DOI: 10.13189/ujer.2021.090123.

Copyright $\subseteq 2021$ by authors, all rights reserved. Authors agree that this article remains permanently open access under the terms of the Creative Commons Attribution License 4.0 International License

\begin{abstract}
School closures, online education, public health, and economic crises pose significant challenges for students, teachers, and governments. This qualitative research describes the education gap in Latin America, its social tensions, and disparities. Furthermore, it explains theoretical concepts such as subjectivities, subjectivation, governmentality, technologies of power, technologies of the self, ethics, normalization, agency, and interculturality. These are some of the researcher's areas of expertise. It also presents the actions taken by Colombia and Mexico to guarantee access to education and digital devices, as well as high-quality contents, interactions, and tasks, during the deadly spread of the COVID-19 pandemic. The results show that education policies do not adequately address student diversity and do not ensure equity in education. The situation has magnified deep-rooted socioeconomic, racial, and educational injustices. The education system has been designed for homogeneous groups, middle and upper-class students, and individuals who are not related to minority groups. The majority of economically vulnerable students cannot access educational resources, have dropped out of school, have experienced interruptions in the learning process, and have developed psychological disorders. Neither teachers nor students have the opportunity to participate in public policy design, hindering the possibility of exercising their "agency" and socializing contributions that could lead to large-scale social transformations in their countries beyond their schools' borders. The article reveals the voices of students, teachers, and parents. Additionally, it proposes approaches and strategies that teachers, students, and governments should apply to promote
\end{abstract}

diversity, critical thinking skills, and interculturality. These elements contribute to the accomplishment of social justice, equity, and authentic democratic processes. Indeed, education should assist the students in acquiring solid foundations to use their "technologies of the self," value diversity, decide, and do not let hegemonies control them through "normalization." Finally, it suggests questions that teachers should reflect on to be creative in their teaching practice, innovate and widen their students' learning and motivational possibilities.

Keywords COVID-19, Diversity, Education Policy, Inclusion, Inequity, Interculturality, Online Education, Subjectivities

\section{Introduction}

Latin American region stands a humanitarian crisis derived from political instability, corruption, injustices, social inequities, violence, unaffordable frail health systems, and few possibilities to access adequate and high-quality education when students are not affluent [1]. In addition to the challenging situation that the region has experienced due to the Coronavirus pandemic, Latin America and the Caribbean region have suffered the worst economic crisis in the last 120 years. In 2020 it marked a contraction of $-7.7 \%$, which probably will recover by $3.7 \%$ in 2021 [2]. However, the economic recovery will be low, and it does not guarantee equality of educational 
opportunities, the promotion of diversity, and social cohesion. Colombia and Mexico have struggled with adverse academic and social issues before and during the COVID-19 pandemic because they have been in a perpetual economic recession.

The world endures unforeseen situations considering that times are liquid [3]. Although the outbreak of coronavirus disease is neither the first nor the only concern humanity has and will have to handle, it has impacted personal, family, social, political, economic, and educational dynamics. In response to current circumstances, online relationships prevail over physical contact. Health measures have led to compulsory or voluntary social isolation, and governments have determined that schools provide online classes for students.

School closings affect around 156 million students in Latin America and the Caribbean [4]. This episode has worsened the social and economic inequities they suffer, considering that many cannot meet their basic needs in Colombia and Mexico. Herein, in Colombia, on March 16, 2020, schools announced the suspension of all physical program delivery to migrate to a virtual learning environment. It has been predominantly shocking in areas where neither institutions nor students have the technological and cognitive resources, as well as the predicament of adapting the online learning methodology for individuals with visual and hearing disabilities [5]. Similarly, in Mexico and Colombia, less than 50\% of students in rural areas have Internet access at home, the percentage being $27 \%$ and $35 \%$, respectively. In Latin America, only 33\% of schools have sufficient bandwidth or internet speed [6]. Aggravating the situation, students rarely have the motivational and material conditions to continue studying, so the United Nations Procurement Division has predicted that 800000 students in Mexico who are currently in the third year of secondary school will drop out of the school system in the remainder of 2020 [7].

\section{Conceptual/Theoretical Issues}

\subsection{Subjectivities and Related Terms}

Power is dynamic and omnipresent. It exists in all relations and discourses: academic, institutional, cultural, political, professional, religious, and social [8]. There are tensions, discussion, silence, submission, and resistance in all relationships. One of the most controlling forms of power is "normalization" because it establishes "regimes of truth." It is not physically repressive, but through "normalization," the masses discipline, supervise and control themselves and others. "Normalization" establishes what can be said and done. It determines what actions and ideas are correct, incorrect, acceptable, unacceptable, desirable, or insignificant. Also, it approves or disapproves propositions, knowledge, and understanding.
The "technologies of power" mediate social relations. These technologies are neither artifacts nor devices but techniques that attempt to normalize the masses' feelings, ideas, beliefs, judgments, and choices. Governmentality consists of discursive or non-discursive approaches that authorities use to produce subjectivities, yearnings, and behaviors on the population [9].

When individuals adopt ideologies, they translate discourses into actions and read the world through the perceptions embedded in the discourse itself. The biopolitical sphere disseminates subjectivities. Once elites, government, and commercial parties exercise the power of creating subjectivities on people, they dominate them. Individuals exert control in different ways:

- They subjectivize to the criteria established by the "technologies of power."

- They reproduce concepts and ideologies spread by the "normality."

- $\quad$ They decide to think and act as they believe and not as others suggest.

Subjects are composed of subjectivities that are always fluctuating. Subjectivity is the individuals' essence because it regulates their personal, social, academic, and political perceptions, interpretations, and relations. Since subjectivities are in permanent construction, humans' nature is not static, fixed, or rigid. Individuals are always exposed to multiple advertisements, knowledge, political decrees, tendencies, news, and interactions. They assume specific positions of "agency" concerning the social relations that are around them. According to the subjects' analytical and critical-thinking levels, they build their identity, values, beliefs, and convictions. People who do not analyze and contrast information are vulnerable to being easily oppressed and subjectivized to ideologies and regimes of truth. They may think that they decide independently, but the reality is that their minds and actions are manipulated. Discourses are influential because they reproduce and perpetuate power relations. When human beings let that discourses govern their thoughts, the consequences are that those messages regulate their bodies, mediate their relationships, and determine how they interpret the world.

From an ethical perspective, the development of the "technologies of the self" consists of how individuals are autonomous agents that decide, taking into account equality and the common good. Ethics does not refer to religion or moral codes. It defines the capacity of people to preserve their dignity and that of others [10]. Ethical individuals are not docile bodies; instead, they control their thoughts and actions, becoming agency-oriented individuals within their contexts. Therefore, an ethical "agency" refers to the skill of deciding autonomously and consciously. It involves evaluating choices, analyzing, making propositions, defending their arguments, accepting subjectivities that they consider accurate. On the other hand, individuals resist ideologies and behaviors that are 
not constructed according to their convictions.

\subsection{Critical Interculturality}

When individuals value diversity, they critically understand its contribution to humanity, the trials, and challenges that cultures have faced, their background, development, and outcomes, as well as different ways of conceiving the world [11]. Interculturality promotes plurality, epistemologies, people's dignification, and all groups' identities and potentialities [12].

Hegemonies of power have oppressed and silenced communities and groups that do not share their same aims [13]. In response to that, interculturality uses critical thinking skills to respectfully analyze, discuss, and question the functions and relationships among languages, cultures, society, and political parties through history until the present times. Individuals who have developed their intercultural competence are self-aware, know about others, and are able to explain with arguments why there are certain cultural practices and perspectives. They generate ideas to struggle against the loss of identity and the promotion of ethnocentrism and eurocentrism. They interact, reflect, and make exchanges with people from diverse ethnicities, beliefs, languages, nationalities, and religions in a polite and sensible ambiance. They also generate ideas to adequately participate in social and cultural relationships with people from other cultures without losing their essence and identity.

Through interculturality, individuals argumentatively analyze how elites and society reproduce bias about languages, cultures, and populations. Interculturality examines and counterargues stereotypes, inequity, exclusion, racism, hegemony, the lack of political and social participation of minorities, and domination. Indeed, it highlights the importance of fostering diversity, equity, and respect for human rights.

\section{Methodology}

The current study applied the qualitative paradigm to interpret how social phenomena and education are directly related [14]. The documentary research, as well as the researcher's theoretical and practical knowledge, experience as a professor in Colombia, and exchanges with Universidad Autónoma de Aguascalientes in Mexico, were vital to retrieve the information. For this reason, the researcher has in-depth knowledge of Mexican and Colombian realities. The research is the result of critical hermeneutical analysis consisting of five stages [15]: 1 . Tracing research on Colombian and Mexican teachers' subjectivities in the face of education policies and realities of academic actors to contrast similarities, differences, and challenges; and tracking of publications from Colombia and Mexico that made it possible to discern the trials of the education systems. 2. Classification of documents through an informative summary matrix to synthesize the findings generated in each investigation. 3 . Selection of information considering the criteria of the publication date, country, research topic directly related to education. 4. Analysis of the selected publications. 5. Confrontation of educational situations in both countries, to contrast them.

The current study's significance lies in the fact that it is one of the first studies to focus on contrasting the Mexican and Colombian education system's response to online teaching during the COVID-19 pandemic. Besides, it describes Mexico and Colombia's subjectivities towards democratic education, technology, diversity, inequity, and interculturality. This study contributes to giving a wide range of suggestions that should be followed to help students' academic, emotional, and social progress and teachers' creativity, innovation, and excellence in their professional path.

\section{Results}

\subsection{Students' Segregation and Academic Achievement Gaps}

There are around 36518721 million students within the National Education System in Mexico [16]. For most of the year 2020, students have been studying remotely. The National Commission for the Continuous Improvement of Education in Mexico has announced publically that, in the country, there are multiple kinds of students, scenarios, and cadences. For this reason, it suggests strengthening solidarity, shared knowledge, academic, financial, emotional support, meal plans for students, and educational resources [17]. Colombia and Mexico use digital content, television, and radio to cover educational continuity. While Colombia has the educational portal "Colombia Aprende," with around 80000 digital educational resources available to teachers and students on a wide variety of educational topics, Mexico has a digital library furnished with textbooks, books, guides for teachers and parents [18]. Despite the efforts, it is estimated that in Colombia, between March and July 2020, students had not reached approximately $26 \%$ of the learning that they would have acquired under normal conditions [19]. As shown in table 1, Mexico and Colombia count on various educational broadcasts through television, radio, apps, digital educational resources, and educational platforms [20]. 
Table 1. At-Home Learning Resources During the COVID-19 Pandemic in Colombia and Mexico

\begin{tabular}{ll}
\hline Country & \multicolumn{1}{c}{ Resources } \\
\hline & "Estrategia de Educación a Distancia: transformación e innovación para México" that provides tools to teachers, \\
& students and parents. \\
& National Program: "Aprende en Casa." \\
& Educational programs broadcasted on TV Azteca. \\
& Aprende TV. \\
& Capacita TV. \\
& Centro de capacitación televisiva y audiovisual. \\
& México X. \\
& TV broadcasts organized by educational levels: Telebachillerato 17 EDUSAT; Telesecundaria 11 EDUSAT; \\
& Telesecundaria 27 EDUSAT. \\
& Online broadcasts in: www.sep.gob.mx; www.televisioneducativa.gob.mx, and www.onceninos.tv \\
& Educational materials published $\quad$ in: $\quad$ www.aprende.edu.mx; \\
& www.librosdetexto.sep.gob.mx \\
& "Kit de aprendizaje en casa" for students without digital connectivity. \\
& Digital App: "\#BeThe1Challenge" for strengthening English skills. \\
& Digital educational resources in the platform "Aprender digital, contenidos para todos," "Colombia Aprende." \\
& Educational programs broadcasted on Canal 13, Canal Capital, Canal, Institucional, Canal TRO, RTVCPLay, Señal \\
& Colombia, Tele islas, TeleAntioquia, Telecafé, Telecaribe, Telepacífico. \\
& Educational TV content from 6 a.m. to 6 p.m.: Strategy 3, 2, 1 Edu-Acción. \\
& Radio Nacional de Colombia, Colmundo Radio. \\
& Variety of educational TV broadcasts in "franja educativa" in Señal Colombia and "profe en tu casa." \\
\hline
\end{tabular}

Even though these strategies are positive, and governmental institutions' speeches are about democracy, equality, and protection for all students, the reality is entirely different. Governments do not care about minority groups [21] because one embedded subjectivity in Mexico and Colombia is that they are not valuable human beings. They consider them as unproductive people who do not contribute anything relevant to society. This conception is also subtly disseminated in propaganda, newspapers, and textbooks, highlighting the supremacy of foreign lifestyles, languages, and cultures through discourses or images [22]. The consequence is the reproduction of racism, stereotypes, and conceptions that hierarchize cultures, countries, and races, impacting the population's attitudes, beliefs, and actions.

The marginalized groups, Indigenous, immigrant, and black students, are less likely to obtain priority, attention, financial and academic support from the governments [23], [24]. While students with high socioeconomic status have plenty of opportunities to keep studying and learning, those with meager resources tend not to exercise their right to education and have an alarming risk of bearing psychosocial issues [25]. Students are living in harsh circumstances. At least one family member is currently unemployed because of the economic crisis generated by the COVID-19 pandemic. Therefore, the main reason why students have dropped out of school is that they cannot pay tuition, lack internet or device access, or work to contribute economically to their households. Some students express that they feel helpless and isolated, cannot concentrate at home, suffer from psychological distress, or are mistreated at home.

In Latin America, 46\% of students between 5 and 12 years old cannot straightforward access online education [27]. These learners do not have access to computers, smartphones, tablets, Wi-Fi, television, or even radio [26]. It has been a tradition for Mexican and Colombian governments to marginalize the population because of their economic situation and race, so they provide fewer resources to those who need them more: public schools, Indigenous communities, and rural areas. Evidence of this problem is that, before the pandemic, when low-income students attended school, most of them had to deal with inadequate school infrastructure, lack of facilities, scarcity of educated and trained teachers, and overcrowded classrooms [28], [29]. The corollary is that right now, Indigenous, ethnic minorities, and impoverished students have minimal access to computers: in the Dominican Republic, 13\%, in Mexico 10\%, in Peru 7\%. In Colombia, the reality is not reassuring either since at the regional level, in $96 \%$ of the country's municipalities, less than half of the students have access to the technological tools needed to receive online classes; being the southeastern region of the country, the one with the most significant lags [30].

These economically vulnerable students have limited options to learn and interact, which has caused them profound learning gaps. Some students cannot attend online synchronic classes, ask questions, solve doubts in real-time, download didactic material, access video conferencing, upload their tasks, receive feedback, share their ideas and listen to others. While some fortunate students have high-speed Internet service at home, others have unreliable or nonexistent internet access, making them susceptible to falling behind academically and getting easily unmotivated. The results are higher levels of grade repetition and dropout rates and lower learning achievements in comparison to students who represent the "normalization," not because they lack intellectual skills. It is due to social and educational segregation and rough obstacles to access to learning opportunities. For example, 
research made in Chiapas, Mexico, pinpoints that Mexican national programs and, specifically, its local program "My School at Home" are palliative mechanisms that do not solve the problems of poverty and educational backwardness that students have always experienced [31]. Indeed, even though there are plenty of learning resources, not all students can take advantage of them. They cannot complete assignments with the same efficiency as students with a more prosperous economic situation because they can concentrate on their studies, have school supplies, and have fewer concerns. The result is that, before and during the pandemic, many students have performed poorly. In fact, they have failed to meet national goals in terms of competencies and knowledge. The impact on society is that schools are always losing students, and the countries miss the opportunities of training students who make the territories grow ethically, academically, technologically, scientifically, humanistically, and economically.

\subsection{Parental Support and Communication with Schools}

The digital divide and social injustices have become a chasm, and students need their families' help. Living in a peaceful ambiance at home is decisive since these are the fronts that can favor or undermine students' educational, emotional, and social processes and contribute to their development. In small towns, rural areas of Mexico and Colombia, and some states of Mexico such as Aguascalientes, most families are united, have cultivated strong links with their children, and have a close relationship with schools. In contrast, there is a tendency of low parental engagement in students' learning processes in vast territories and urban areas. Over time, in Colombia, parents have not been prone enough to establish links to the schools, even though their support is required to achieve academic success [32] [33].

Nowadays, parents should establish the links that they did not develop before the pandemic. Their support is essential in their children's emotional and academic improvement, especially in tough times of lockdown [34]. As seen in figure 1 , the empirical results show that communication with parents in Mexico tends to decrease over time [35]. In this respect, when students cannot count on their families as co-educators, they experience more difficulties exploring all their academic skills. They are likely to feel discouraged and perceive knowledge as something unimportant and uninteresting. Moreover, if they need extra explanations at home, they do not receive their parents' support.

Consequently, if learners are not autonomous enough, they stop studying. Instead, they get interested in other activities. Parental negligence makes students feel that they are alone in their learning process, they get distracted easier, and it gets difficult for them to concentrate on academic tasks. Eventually, they limit their studying and practicing times, so they do not explode their potential. Unfortunately, in pandemic times, in Mexico, $43 \%$ of parents have not experienced good communication with schools; $20 \%$ indicate that the relationship with schools has been very fluid, and 34\% say that it has been fluent. On the other hand, $20 \%$ of parents state that the communication has not been eloquent, and $23 \%$ say it has been feeble. Also, 39\% declare that teachers have answered their questions and followed their suggestions, while $27 \%$ have not had positive communication with schools [36].

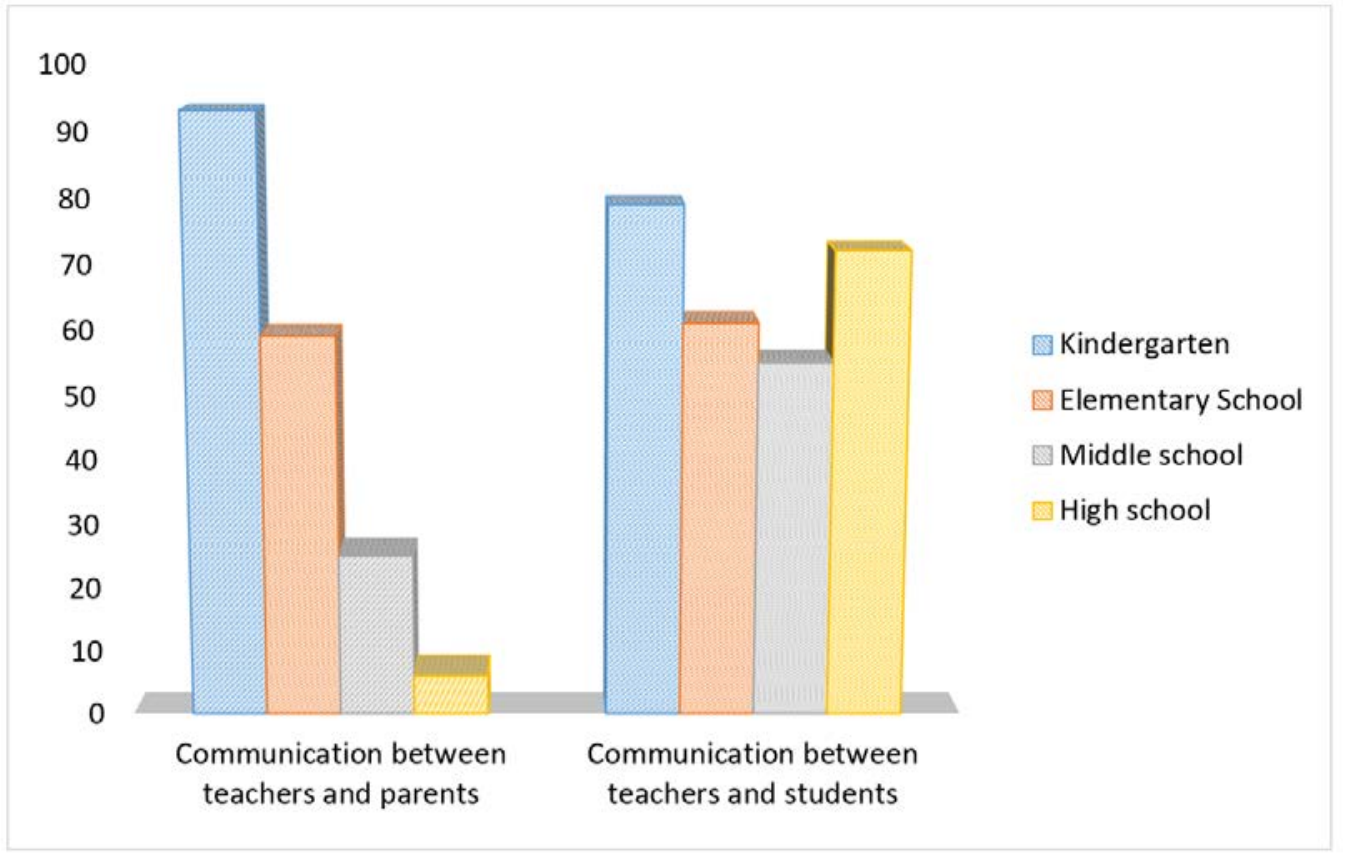

Figure 1. Parent-teacher and Student-teacher communication through the students’ academic path 
Fortunately, some teachers are committed to democratic education and social justice. They are willing to help students to succeed in this new learning path [37], [38], [39], [40]. This is positive because they have robust levels of individual responsibility, accountability, and liability to goad academic success for all students. Teachers make great efforts and tasks to provide an excellent education to the students. Nonetheless, teachers' issues are titanic because some have suffered emotional exhaustion and anxiety derived from high-stress levels. Teachers have endured the pressure of the overnight switch of teaching remotely, and it requires professional knowledge and training. Parents have also been impacted because online learning is time-consuming, which is seen as a burden for some of them. Others are frustrated because some students do not have the means to smoothly access technological tools and access online classes. Besides, most students do not have adequate self-control abilities to concentrate on their online learning tasks. Some of the Mexican teachers' concerns are paraphrased: "I am unmotivated because, although I do what I can, I miss the dynamics of the school and the direct relationship with both the students and my colleagues. In short, not having contact with other teachers and students does not fill me up at all;" "The administration does not specify our tasks. I spend much more time solving technical problems of the students and myself and doing bureaucratic tasks than preparing the classes and correcting homework" [41]. Consequently, they should be psychologically, technically, and academically supported to keep developing their pedagogical practice for the demands and expectations of parents, students, communities, government, and societies in the modern world.

\subsection{Quality of Online Education}

According to an empirical study carried out in Mexico, most parents pinpoint that their children are not receiving a high-quality education. Parents have the subjectivity that online classes are detrimental to learning, and students are not learning efficiently. The following are paraphrased comments of Mexican parents and students about remote education [42]:

\section{Parents' opinions:}

"Although the effort was good and schools gradually incorporated interesting things, I feel that the work with the students was not enough."

"Hopefully, when children return to the classrooms, they will do more activities to learn more. They have wasted time during online education."

"Hopefully, when they return, they will do more activities to promote learning due to wasted time."

"You cannot compare a daily routine of four hours of class in the classroom with 30 minutes of online classes; of course, there will be deficiencies in learning due to contingency."

\section{Students' opinions:}

"I don't know why we stopped going to school; sometimes, I don't understand the classes on the screen, and I miss my friends."

"I really liked what we did on the computer. But I learn more at school. I talk more at school with my friends."

According to these subjectivities, parents believe that online learning has kept their children from having access to high-quality education. These subjectivities are unfavorable because the swift that parents, students, and teachers have lived was abrupt. They have had low readiness levels in online classes. For this reason, they have faced failure and low percentages of achievement. Students miss their classmates, their games, and the freedom they have in the classroom to ask questions and have social contact with teachers, peers, and other members. They have felt forced to e-learn, which reinforces negative perceptions towards online education. Neither the parents nor the students had the time to prepare to interact online successfully, enhance self-directed learning, learn to manage the time, the spaces, and the technical tools, boost their motivation toward e-learning, engage in online activities, and be autonomous learners.

On the other hand, there are positive subjectivities of online learning:

\section{Parents' comments:}

" You have to recognize the efforts of teachers and children; I liked the tasks like the forms and capsules that helped them a lot."

"Thank you for all your support, for the great effort you make to continue with the best student learning. I congratulate you for using the digital tools."

\section{Students' comments:}

"They help increase my skills because I did not know how to use some Google applications."

"At the beginning, I was nervous because I did not know how the classes and activities were going to be. Later, I got used to that way of taking classes."

It is identified that most of the positive subjectivities are generated by parents and students who are in proper environments furnished with the resources and conditions to give and receive online classes. Furthermore, the students with better results are from privileged backgrounds, have supportive families and teachers, and are eager to learn. These subjectivities demonstrate that online education is not, by itself, harmful to learning performance. It should be used to inspire more educational ideas at home and online. 


\subsection{Teachers' Role}

Researchers in Colombia indicate that teachers need to be trained in the pedagogical use of ICTs (Information and Communication Technologies), TPACK (Technological Pedagogical Content Knowledge), and the implementation of new methodologies of online teaching and learning [43]. Formal training for teachers sponsored by the government is imperative since the situation is not encouraging in Colombia: $48 \%$ of public schools' principals consider that their teachers do not have the technical and pedagogical skills to integrate digital devices into teaching [44]. Through digital training, teachers develop their expertise in various digital tools and platforms that they can use to design innovative activities in their classes, adapt them according to the contents and their students' characteristics, and help students enhance 21st-century skills through collaboration.

It is also crucial that governments give them the freedom to exercise their "agency" in pedagogical practices. They should be allowed to execute actions oriented to help students in their educational processes amid the framework of academic, social, and economic disparities that they experience [45]. Unfortunately, neither Mexico nor Colombia provides teachers professional independence to make autonomous decisions about what they teach to students and how they teach. One evidence is that they are not invited to participate in the education policy's design. So, they do not emancipate to carry out their subjectivities into their teaching practice. In both countries, the education policy limits the educators' authority, responsiveness, creativity, and effectiveness. At the same time, the media question their knowledge and skills [46], [47] [48], [49], [50], [51]. The Mexican and Colombian society has noticed these discourses and decisions. They have built the subjectivity that teachers are not well-prepared, assertive, and capable of showing ingenious initiative. These subjectivities and actions undermine teachers' professional status and expertise. The dissemination of these negative subjectivities undermines teachers' professional status and expertise. Moreover, stringent official regulations stifle teachers' instructional creativity and responsiveness. The outcomes are higher job dissatisfaction, shame, and attrition rates among teachers.

Moreover, the persistent consequence of extreme pressure on teachers eventually makes them abandon their professional role, subjectivize, do not train their "technologies of the self," accept "normalization," and become technicians who follow instructions. This is detrimental for the students because diversity and singularities are not taken into account in public policy. Thus, it should be recognized that teachers are in the best position to make informed decisions about students' education. During the pandemic and in the future, they should be given as much autonomy as possible when choosing instructional strategies, designing lessons, and providing academic support. Given that no policy applied to all teachers can consider student diversity and their myriad abilities and needs, relevant decisions about educating students should be left to teachers; what is required in education henceforth is flexibility, innovation, and understanding.

\section{Discussion}

The results obtained indicate that there is a tendency to reject diversity. Curricula, discourses, and education policy embolden westernization. It affects the population's cultural, cognitive, attitudinal, emotional, and social dimensions. Intercultural education is not a priority for governments and schools. Therefore, neither teachers nor students are skilled enough in intercultural competence, reflexive learning, critical thinking skills, and inclusion. The research identified that the concept of interculturality in schools has been marginalized and reduced to the representation of holidays, tourist places, typical food, traditions, and dances. There are no official efforts to design curricula that explore content about cultural development and meanings. Students are not asked to research and discuss ideologies, segregation, racism, local and foreign cultural minorities, hegemonic practices, social issues, religious beliefs, and laws. Consequently, students have insufficient and biased knowledge about different cultures, which hinders them from developing their cultural competencies to understand, question, meditate, interpret, and have a welcoming and critical thinking approach to diversity.

Another problem is that teachers do not have the freedom to perform their "agency," and they have to fulfill the official curriculum's topics. There is little time to approach other vital issues outside education policy. This lack of knowledge perpetuates the reproductive practice of racism, exclusion, social discrimination, xenophobia, and segregation. It is impossible to ignore the essence of diversity in Colombia and Mexico, not only on a cultural level but also on a social, economic, and personal degree. In search of democratic education, it is necessary to strengthen inclusion. In response to the recent waves of hegemonic neoliberal colonialism that hit Mexico and Colombia, interculturality requires significant betterment. Colombia and Mexico are reproducing the vicious circle of stigmatization, non-critical thinking, and hierarchization. Therefore, it is necessary to demolish the hierarchies of languages, cultures, and social conditions.

School closures due to the coronavirus pandemic have aggravated inequities and digital disparities. Even though the governments and the schools state that they are inclusive, they have not designed flexible curricula that can be adjusted to promote diverse cultural, social, and aesthetic values. Governments admit that it is essential to help students who lack the elements needed to make remote learning possible, such as a computer, Wi-Fi 
connection, a quiet place to do schoolwork, and engaged schools and teachers with technological and pedagogical resources. Nonetheless, governments' actions have not been enough to solve the problem. As a consequence, students keep suffering from cognitive losses. Governments and schools in the analyzed countries fail to implement pedagogical practices and contents that better suit the students' needs, culture, resources, expectations, and projects. Ignoring these aspects results in the reproduction of unfair practices inside the schools and society. When schools promote restricted ideal lifestyles, they enhance prejudices and stereotypes against everything that does not represent westernization.

Social inequities' upshot is the perpetual separation of the privileged students who have access to online learning and those who do not, usually from rural and peripheric areas or whose per capita income is low. Vulnerable populations cannot attend online classes and participate in synchronic interaction. They feel isolated from their teachers and partners, develop significant cognitive gaps that are hard to close, and are prone to fail the courses or dropout. This situation has profound implications in their lifetime because most students finish their education early and never return to school, which inexorably increases crime, poverty, and financial burden to society. It also decreases the countries' possibilities to advance in science, literature, arts, and technology.

It should also be mentioned that not only students suffer from socioeconomic issues. Some educators do not have high-speed wireless access or lack computing devices at home, have limited physical spaces to give their classes, and have to deal with personal issues at home related to their families or housemates. Hence, in many cases, the quality of education tends to decrease. Teachers have not received initial or in-service training to use technology fluently and use efficient online teaching methodologies. Teachers are ethically engaged, but most of them are not trained in distance teaching-learning, so they have had to learn on the go, sometimes making efficient classes but sometimes making severe mistakes.

Teachers must identify their deficiencies in order to solve them. That way, this new process of online education could serve as an opportunity for improvement. This paper identifies some errors that should not be made anymore in online classes and recommends that teachers are aware of them to modify their pedagogical practices:

- re-create the classroom methodologies, activities, interactions to the online courses. It should be avoided because the learning spaces are different and require other approaches; it overwhelms teachers and students; digital opportunities are not explored, and the learning experience is tedious.

- $\quad$ reproduce traditional education in which the teachers are the center of the learning process. When the teachers are the only ones who talk, students disengage. On the contrary, teachers should promote participation, interaction, and collaborative learning.

- give high amounts of homework with tasks that do not require to reflect. Teachers should remember that excess of assignment is not inherently good, and in most cases, leads to boredom and little knowledge. Homework is detrimental when it demands the reproduction of concepts and lack deep-thinking processes because students' perception is that its purpose does not go further than writing extensively to show evidence that they have devoted many hours "studying." The primary purpose of doing so is to keep their grades up and pass a course. Most students get unmotivated and, to do homework, they tend to make digital cheating through copy-paste plagiarism. Instead, this research suggests that teachers propose learning activities that make emerge reflection and deep thinking processes in which students become involved as they generate ideas and opinions, improving their critical thinking skills. Teachers should provoke students that, through homework, they develop their talents and abilities, do specific research, interact with their families, and present original conclusions and proposals. That way, students achieve learning outcomes, spend time with their families, foster personal responsibility, and generate knowledge.

- expect high attendance rates even when students have Wi-Fi issues, their relatives need the computer, or have to take care of their siblings. Teachers should be flexible and understand the students' situations. Therefore, the time that they spend with the students should be meaningful. Teachers should encourage them to develop skills rather than reproduce content and give opportunities to talk and have social time since a complete learning process involves this balance.

\section{Conclusions}

The elements that determine the low, moderate, or high cognitive success of students in online learning are: the conditions of the students' workplace; emotional, material, and digital resources; technological dexterity; type of online pedagogy; time management skills; the possibility of choosing from a variety of activities used in the class; task diversity; frequency in which debate, reflection, dialogue, knowledge production, analysis, and critical thinking skills are promoted; quality of the contents. The lack of adequate resources explains that some students are disadvantaged in online learning. Marginalized students without access to digital tools, with poor resilience skills, surrounded by parents who do not support their learning processes or teachers who make generalizations and judge them, are negatively impacted by school closure and online learning.

A democratic education oriented to social justice and 
equity does not compel students to acquire and reproduce a single identity or knowledge. Instead, it recognizes that every culture contributes to humanity and intends to offer options that decolonize minds. Teachers should use online learning to promote pluralism and interculturality through transformative education. This process involves critical reflection, argumentative discourses, and action. Such an approach encourages learners' engagement and interaction with the plural society that is around them. It also ensures tolerance, respect, flexibility, and eagerness to learn from others and share their knowledge. Research has suggested that to maximize online learning benefits, there is a need to harness resources. Online education should be used to propose tasks to become autonomous, diligent, and transform data into information through inquiry.

Teachers' expertise, experience, recommendations, plans, and subjectivities are not influential in the political sphere. They are not an active part of official decisions regarding education. Once teachers identify power relations, limitations, and opportunities to execute their subjectivities, they will be able to develop more reflexive, critical, intercultural, and inclusive practices. Many would say that society and the education system need to take the first step to achieve pedagogical and social change. Nonetheless, official and non-governmental institutions will positively change when teachers externalize their subjectivities, control their "agency," make proposals that impact education policy, and make ethical decisions. The purpose is to fortress an inclusive, intercultural, and argumentative learning experience for all students.

\section{Recommendations}

Colombian and Mexican students are a heterogeneous population, they have lived different realities, and their main characteristic is pluralism. There is neither monoculturalism nor homogeneity in these countries. COVID-19 lockdown is a wake-up call to the education system because it highlights the importance of exploring students' realities, expectations, abilities, multiple intelligences, and learning styles. Teachers should have mindful behaviors and reshape curricula to provide diverse options that respond to students' particular needs, resources, questions, and motivations in the current vertiginous 21st century.

Schools should be more active in establishing assertive communication with families. Additionally, families should invest time in accompanying and supporting learners' educational activities, and as far as possible, guaranteeing agile and efficient access to digital goods since these are fundamental means of communication in online education. Family is an essential social, cultural, and valuable resource that strengthens supportive emotional ties and provides students with an interdependence that acts as a buffer against adverse situations. In addition, when they work together with schools and communities, students' educational opportunities improve. Furthermore, students' school performance increases when they have highly motivated parents and strong family support since parental expectations play a critical role in developing students' educational ambitions. Thus, it is essential to promote communication and the participation of families in school; facilitate the construction and development of cultural and linguistic identity in their socialization process, and strengthen the students' learning process.

This research highlights the necessity of transformational teachers that:

- assume ownership.

- are flexible to work, collaborate, discuss, and socialize with teachers of the same school, city, region, country, and other nations because exchanges enrich their subjectivities, teaching practice, and ideas.

- are innovative in the use of digital platforms, games, and activities.

- are intercultural and go beyond the boundaries of their knowledge.

- $\quad$ are socially close to students and their parents.

- are supportive and recognize that their students endure different socioeconomic challenges.

- create learning environments where students work collaboratively and interact with their peers.

- develop alternative methodologies and approaches based on their academic and pedagogical expertise. Present times demand changes in the teaching strategies.

- develop technical and pedagogical knowledge of digital tools.

- explain the importance of learning in safe and healthy spaces.

- explore the students' realities to make pedagogical decisions that are essential to them and take into account their context, family situation, socioeconomic status, opinions on various topics, the media around them, and their preferences.

- generate confidence in students.

- $\quad$ help students to understand that mistakes are learning opportunities to refine their strategies and knowledge structure.

- intensify positive coping skills.

- listen to students actively.

- nurture students' intercultural understanding; encourage students to value diversity and develop strong interpersonal ties.

- prepare students to be resilient and to meet current and future challenges.

- provide feedback to their students to improve their metacognitive skills and cultivate learning and development.

- stimulate students to interpret, participate, analyze, ask questions, defend their perspectives, foster critical 
thinking skills, discover what they know and do not know, and have constant knowledge acquisition.

- use students' contributions as a learning tool.

- appreciate students' work and progress and give feedback on their production.

- help students to increase their technological aptitudes.

- work with students, families, and the communities to make curricular reforms that establish precise strategies to eliminate ethnocentrism and westernization. It is recommended that curricula encourage horizontality, dialogue, respect, equality, harmony, and active listening.

To accomplish a democratic education, teachers should actively seek to influence political decisions. In that way, they foster their empowerment and make social transformations. There must be a teacher's voice in everything that concerns education. Hence, teachers should be agents in political action. Teachers' significant problem is that, although they have subjectivities, they do not always put them into action because their job requires them to respond to "normalization," which exerts tremendous pressure on them. It is urgent to revindicate the teachers' agency because they are the ones who know the students, are immersed in the classrooms, and understand what their students need. However, as evidenced in Mexico and Colombia, when it comes to establishing and implementing education policies, the norm continues to be that teachers are not invited to participate in their design. The voice of teachers is a missing piece in governmental decisions related to education. Teachers must recover their agency, be proactive and lead processes that generate transformations in education to foster inclusion and interculturality in the learning processes.

It is complex to get out of the "normalization" that teachers are expected to satisfy, and it is problematic for them to resist because of bureaucratic issues. Nevertheless, teachers must respond to the needs of 21st-century students and go beyond the public policy documents that restrict their subjectivities. They must become active agents in their profession, keep the intercultural and inclusive conversation alive, and do not interrupt the students' inquiries about issues that impact the world. Teachers should let students develop their creativity and reflection. They should also be able to work collaboratively, identify the processes of subjectivation, and question their educational practices, public policies, and contexts surrounding them. These processes are useful to generate tangible transformations in education to boost inclusion, active learning strategies, and the promotion of critical thinking skills.

Some guidelines should be implemented in education policy and be supervised in the teaching practice. For this reason, this paper suggests that to tackle inequity, demotivation, and unsatisfactory academic progress, governments should: -abolish the concept that learning is transactional and means "accumulation of knowledge and the reproduction of concepts."

-collaborate with researchers and English teachers to make national and local programs to support students' online learning processes.

-make the families participate in online activities with the students and share suggestions to enhance online learning.

-develop policies addressing the social, economic, and digital needs of disadvantaged students and schools.

-diagnose the processes of effectiveness and adaptability of students and teachers to modify or maintain education policies.

-eliminate homogeneous and assimilationist strategies because they vanish the value of diversity.

-encourage horizontal and multilateral relationships among government, teachers, students, and parents.

-establish training courses in digital competencies for parents, students, and teachers.

-evaluate if the subjects' contents are inclusive and are open to various knowledge, contexts, and realities.

-propose a non-centralized and non-unidirectional education.

-design critical and decolonial content in the curricula and scholar interactions.

-provide computers, tablets, and Wi-Fi connection to students and teachers who require them.

-offer psychological attention to teachers, students, and their families.

-struggle for social and cognitive justice that claims openness to epistemological diversity.

-take into account teachers' academic knowledge, experiences, proposals, and subjectivities about diversity, equality, and democratization of education.

-overtly promote the value of diversity in advertisements, discourses, policies, meetings, conferences, training courses, and campaigns.

Finally, in every class, teachers should have the habit of answering the questions that this paper proposes in Table 2. The aim is to improve their reflectiveness in their teaching practice, contributing to the betterness of education. When teachers self-explain, they generate inferences, develop self-knowledge, recognize effective actions and mistakes. Furthermore, they attempt to take positive and ethical action in the teaching practice to solve problems, understand student diversity, increase communication with the parents, listen to them, affirm or reconsider notions and pedagogical practices towards education. Effective teachers learn every day; acquire a cognitive understanding of how students learn; develop emotional preparation to relate to all students' needs; draw different ways to present content knowledge; create constructivist experiences for students; make accurate teaching decisions quickly and act on them. 
Table 2. Questions that teachers should reflect on before, during, and after their classes:

\begin{tabular}{|c|c|c|}
\hline Theme & Questions \\
\hline $\begin{array}{c}\text { Classroom } \\
\text { dynamics }\end{array}$ & $\begin{array}{c}\text { How are relationships in teaching and learning practices? How is decision-making done? How are dialogues about } \\
\text { gender / race / language / socioeconomic conditions developed? How are teachers being welcoming to their students? } \\
\text { How do the teachers use online resources, forums, and social media to engage students and make their experience } \\
\text { personal and memorable? How are teachers designing activities to develop peer-to-peer support? How do teachers } \\
\text { collaborate with students and parents? How is parental involvement leading to student success? How are teachers } \\
\text { designing feedback through collaborative exercises that involve the students' participation and contributions? }\end{array}$ \\
\hline $\begin{array}{c}\text { Roles of the } \\
\text { teachers, } \\
\text { students, and } \\
\text { families }\end{array}$ & $\begin{array}{c}\text { How have been the subjectivities of the teachers, students, parents, and government taken into account? What are their } \\
\text { subjectivities? How are their subjectivities useful in online learning processes? How do teachers drive interaction and } \\
\text { exploration? How are teachers promoting formative evaluation and providing feedback to students? How are the } \\
\text { students' and teachers' attitudes during the class? How are teachers offering innovative and practical work? How are } \\
\text { teachers asking high-order thinking questions to students? }\end{array}$ \\
\hline Connectivity & $\begin{array}{c}\text { How do teachers respond to the technological, emotional, and learning needs of students? How do teachers show } \\
\text { flexibility to help students access lectures, written and audiovisual material, and assignments? How do teachers make } \\
\text { students participate, innovate, and engage with online classes even though some students have zero to low-speed } \\
\text { Internet connectivity or do not have digital devices? How efficient is the process of providing laptops, computers, } \\
\text { tablets, or Wi-Fi hotspots to teachers and students? How are the government and the school ensuring digital equity? }\end{array}$ \\
\hline
\end{tabular}

Social changes force teachers to innovate, contrive strategies to use new methodologies and approaches, and reinforce their relations with students, parents, and governments. This paper puts forward that teaching and learning practices must be social, inclusive, intercultural, reflexive, participative, and argumentative. Otherwise, through time, school education will be academically and socially ineffective. Instead of fulfilling the skills that students need for the 21st century, it would hinder learning, full engagement, and well-being.

\section{REFERENCES}

[1] CEPAL, "El impacto del COVID-19 en América Latina y el Caribe," [The impact of COVID-19 in Latin America and the Caribbean], https://honduras.un.org/sites/default/files/2020-07/S G\%20Policy\%20brief\%20COVID\%20LAC\%20\%28 Spanish\%29_10\%20July.pdf. Naciones Unidas. 2020.

[2] CEPAL, “América Latina y el Caribe tendrá crecimiento positivo en 2021, pero no alcanzará para recuperar los niveles de actividad económica pre-pandemia," [Latin America and the Caribbean will have positive growth in 2021, but it will not be enough to recover the pre-pandemic levels of economic activity], https:/www.cepal.org/es/comunicados/america-latin a-caribe-tendra-crecimiento-positivo-2021-pero-alca nzara-recuperar-niveles. 2020.

[3] Bauman, Z, "Liquid life. Cambridge: Polity Press," 2005.

[4] Unesco, "Componentes para una respuesta integral del sector educativo de América Latina frente al COVID-19," [Components for a comprehensive response of the Latin American education sector to
COVID-19], https://es.unesco.org/sites/default/files/c omponentes-respuesta-integral-sector-educativo-alc_ 1.pdf. 2020.

[5] Moreno-Correa, S. M, "La innovación educativa en los tiempos del Coronavirus,” [Educational innovation in the times of Coronavirus], Salutem Scientia Spiritus, no. 61, pp.14-26, 2020.

[6] IDB, COVID-19, “¿Estamos preparados para el aprendizaje en línea?,” [Are we ready for online learning?],

https://publications.iadb.org/publications/spanish/doc ument/Nota-CIMA--20-COVID-19-Estamos-prepara dos-para-el-aprendizaje-en-linea.pdf. 2020.

[7] PNUD, "Desarrollo humano y COVID-19 en México: desafíos para una recuperación sostenible,” [Human development and COVID-19 in Mexico: challenges for a sustainable recovery], https://www.mx.undp.org/content/mexico/es/home/li brary/poverty/desarrollo-humano-y-COVID-19-en-m exico-.html. 2020.

[8] Foucault, M, "El sujeto y el poder," [The subject and the power], In J. Yágüez. La ética del pensamiento. Para una crítica de lo que somos, Biblioteca Nueva. 2015.

[9] Foucault, M, "Nacimiento de la biopolítica: curso en el Collège de France (1978-1979)," [Birth of biopolitics: course at the Collège de France (1978-1979)], Fondo de Cultura Económica. 2007.

[10] Foucault, M, "Power/Knowledge: Selected Interviews and Other Writings, 1972-1977," Pantheon Books, Inc. 1980.

[11] Walsh, C, "Interculturalidad, Estado, Sociedad: Luchas decoloniales de nuestra época," [Interculturality, State, Society: Decolonial struggles of our time], Universidad Andina Simón Bolívar y Abya Yala. 2009. 
[12] de Sousa Santos, B, "The end of the cognitive empire: the coming of age of epistemologies of the South," Duke University Press. 2018.

[13] de Sousa Santos, B, "Epistemologies of the South," Paradigm. 2014.

[14] Galeano, M. E, “Diseño de proyectos en la investigación cualitativa,"[ Project design in qualitative research], Fondo Editorial EAFIT. 2004.

[15] Sandoval, C, "Investigación Cualitativa,” [Qualitative research], ARFO Editores e Impresores Ltda. 1996.

[16] SEP, “Informe de Labores,” [Work Report], https://www.planeacion.sep.gob.mx/Doc/informes/la bores/2018-2024/2do_informe_de_labores.pdf. 2020.

[17] Mejoredu, “10 sugerencias para la educación durante la emergencia por COVID19,” [10 tips for education during the COVID19 emergency], Comisión Nacional para la Mejora Continua de la Educación,” https://www.gob.mx/mejoredu/articulos /10-sugerencias-para-la-educacion-durante-laemerge ncia-por-COVID-19?state=published. 2020.

[18] Banco Interamericano de Desarrollo, "La educación en tiempos del coronavirus: Los sistemas educativos de América Latina y el Caribe ante COVID-19," [Education in times of coronavirus: The education systems of Latin America and the Caribbean in the face of COVID-19], https:/publications.iadb.org/publications/spanish/doc ument/La-educacion-en-tiempos-del-coronavirus-Lo s-sistemas-educativos-de-America-Latina-y-el-Carib e-ante-COVID-19.pdf .2020.

[19] World Bank, "Impactos de la crisis del COVID-19 en la educación y respuestas de política en colombia,"[Impacts of the COVID-19 crisis on education and policy responses in Colombia], http://pubdocs.worldbank.org/en/6416015996650381 37/Colombia-COVID-education-final.pdf. 2020.

[20] Abadía Alvarado, L. K, "El reto que el sector educativo en Colombia debe superar tras la pandemia," [The challenge that the education sector in Colombia must overcome after the pandemic], Hoy en la Javeriana, vol. 59, no. 1355, 2020. https://www.javeriana.edu.co/documents/12789/115 69759/P\%C3\%A1g.+9.+El+reto+del+sector+educati vo.+HJ+marzo+2020+web.pdf/bf0db075-be31-413f8496-e6d72ec72bf9.

[21] ONIC, “Los Pueblos Indígenas De Colombia Rechazamos La Discriminación, Racismo, Estigmatización Y Exclusión Estructural Por Parte Del Gobierno De Iván Duque," [The Indigenous Peoples of Colombia Reject Discrimination, Racism, Stigmatization And Structural Exclusion By The Government Of Iván Duque], https://www.onic.org.co/noticias/3890-los-pueblos-i ndigenas-de-colombia-rechazamos-la-discriminacion -racismo-estigmatizacion-y-exclusion-estructural-por -parte-del-gobierno-de-ivan-duque. 2020.

[22] Corona, S., \& Le Mur, R, "Racismo en la imagen de los indígenas en los Libros de Texto Gratuitos" [Racism in the image of Indigenous people in Free Textbooks], (2012-2015). Comunicación Y Sociedad, (28), 11-33, 2016. DOI: 10.32870/cys.v0i28.5419

[23] UNICEF, “Llamado a la acción de UNICEF. Las comunidades indígenas y el derecho a la educación en tiempos del COVID-19," [UNICEF call to action. Indigenous communities and the right to education in times

of COVID-19], https://www.unicef.org/lac/media/1455 1/file/Llamado\%20a\%20la\%20acci\%C3\%B3n\%20d e\%20UNICEF.pdf. 2020.

[24] FILAC, “Pandemia y Desigualdad: El Derecho a la Educación de los Pueblos Indígenas en la región," [Pandemic and Inequity: The Right to Education of Indigenous Peoples in the region], https://www.filac.org/wp/comunicacion/filac-inform a/pandemia-y-desigualdad-el-derecho-a-la-educacion -de-los-pueblos-indigenas-en-la-region/. 2020.

[25] ONU, "Policy Brief: The Impact of COVID-19 on children," http://www.infocoponline.es/pdf/COVID_ Children_Policy_Brief.pdf. 2020.

[26] EL TIEMPO, "Solo el $17 \%$ de los estudiantes rurales tiene Internet y computador," [Only 17\% of rural students have Internet and $a$ computer], https://www.eltiempo.com/vida/educacio n/solo-el-17-de-los-estudiantes-rurales-tiene-internet -y-computador-495684. 2020.

[27] CEPAL, "Universalizar el acceso a las tecnologías digitales para enfrentar los impactos del COVID-19," [Universalize access to digital technologies to face the impacts of COVID-19], https://www.cepal.org/sites/default/files/presentation /files/final_final_COVID19_digital_26_agosto.pdf. 2020.

[28] Rojas Rojas, S. E, “ ¿Se puede hablar de equidad en el sector educativo colombiano?," [Can we talk about equity in the Colombian educational sector?], Rev. Cient. Gen. José María Córdova, vol. 16, no. 23, pp. 125-143, 2018. DOI: 10.21830/19006586.286.

[29] Miranda López, Francisco, "Infraestructura escolar en México: brechas traslapadas, esfuerzos y límites de la política pública,” [School infrastructure in Mexico: overlapping gaps, efforts and limits of public policy], Perfiles educativos, vol.40, no. 161. 32-52, 2018.

http://www.scielo.org.mx/scielo.php?script=sci_artte xt\&pid=S0185-26982018000300032\&lng=es\&tlng= 
es.

[30] IDB, “COVID-19, ¿Estamos preparados para el aprendizaje en línea?,” [COVID-19, Are we ready for online learning?], https://publications.iadb.org/publications/spanish/doc ument/Nota-CIMA--20-COVID-19-Estamos-prepara dos-para-el-aprendizaje-en-linea.pdf. 2020.

[31] Mérida Martínez, Y., \& Acuña Gamboa, L. A, "COVID-19, Pobreza y Educación en Chiapas: Análisis a los Programas Educativos Emergentes,” [COVID-19, Poverty and Education in Chiapas: Analysis of Emerging Educational Programs], Revista Internacional De Educación Para La Justicia Social, vol.9, no. 3, pp. 61-82, 2020. DOI: 10.15366/riejs2020.9.3.004

[32] Romero, G., Martínez, J., \& Londoño-Vásquez, D, "El acompañamiento familiar en el proceso de formación escolar para la realidad colombiana: de la responsabilidad a la necesidad," [Family support in the school training process for the Colombian reality: from responsibility to need], Psicoespacios. vol. 11, no. 196, 2020. DOI: 10.25057/21452776.88.

[33] García Jaramillo, S, "COVID-19 and primary and secondary education: the impact of the crisis and public policy implications for Latin America and the Caribbean," [COVID-19 and primary and secondary education: the impact of the crisis and public policy implications for Latin America and the Caribbean], UNICEF. 2020.

[34] Amaya-López, L. F, “El papel del vínculo psicoafectivo familiar en el tránsito de la educación presencial a la educación virtual y remota en el marco de la emergencia sanitaria por la COVID-19.” [The role of the family psycho-affective bond in the transition from face-to-face education to online and remote education in the framework of the health emergency caused by COVID-19], Búsqueda, vol.7, no. 24. e492. 2020. DOI: 10.21892/01239813.492.

[35] Baptista Lucio, P., Almazán Zimerman, A., \& Loeza Altamirano, C. A, "Encuesta Nacional a Docentes ante el COVID-19. Retos para la educación a distancia," [National Survey of Teachers before COVID-19. Challenges for distance education], Revista Latinoamericana De Estudios Educativos, vol.50, no. especial. pp. 41-88. 2020. DOI: 10.48102/rlee.2020.50.ESPECIAL.96.

[36] Iraola, E. A., López, N. L., \& Rodríguez, N. N, “COVID-19. Desescolarización involuntaria: las familias y la escuela frente al espejo,” [COVID-19. Involuntary unschooling: families and the school in the mirror], Universidad del País Vasco. 2020.

[37] Angel, S. y Martín, S, “Tiempo en pandemia Vivencias de estudiantes universitarios durante la coyuntura epidemiológica en Colombia," [Time in pandemic Experiences of university students during the epidemiological situation in Colombia], pp. 1-159, 2020. DOI: $10.22518 /$ book/9789584893581

[38] Bracho, K.J., \& Bracho, M. Ch., "COVID-19: Frente al desafío pedagógico de lo presencial a lo virtual," [COVID-19: Facing the pedagogical challenge of physical attendance to online education], Hamutay, vol.7, no. 2. pp. 9-17, 2020. DOI: 10.21503.

[39] Hall, J. A., \& Ochoa-Martínez, P. Y, “Enseñanza virtual en educación física en primaria en México y la pandemia por COVID-19," [Online teaching in physical education in primary school in Mexico and the COVID-19 pandemic], Revista Ciencias de la Actividad Física UCM, vol. 21, no. 2, julio-diciembre, pp. 1-7, 2020. DOI: 10.29035/rcaf.21.2.4.

[40] Martínez-Garcés, J., \& Garcés-Fuenmayor, J, "Competencias digitales docentes y el reto de la educación virtual derivado de la COVID-19. Educación Y Humanismo," [Teaching digital skills and the challenge of online education derived from COVID-19. Education and Humanism], vol. 22, no. 39, pp. 1-16, 2020. DOI: 10.17081/eduhum.22.39.4114.

[41] Iraola, E. A., López, N. L., \& Rodríguez, N. N, “COVID-19. Desescolarización involuntaria: las familias y la escuela frente al espejo,” [COVID-19. Involuntary unschooling: families and the school in the mirror], Universidad del País Vasco. 2020.

[42] Faro educativo, “El COVID-19 y la educación. La experiencia en una escuela de educación básica en México," [COVID-19 and education. The experience in an elementary school in Mexico], 2020. https://faroeducativo.ibero.mx/2020/09/29/el-COVI D-19-y-la-educacion-la-experiencia-en-una-escuelade-educacion-basica-en-mexico/.

[43] Abadía Alvarado, L. K, "El reto que el sector educativo en Colombia debe superar tras la pandemia," [The challenge that the education sector in Colombia must overcome after the pandemic], Hoy en la Javeriana, vol. 59, no. 1355, 2020. https://www.javeriana.edu.co/documents/12789/115 69759/P\%C3\%A1g.+9.+El+reto+del+sector+educati vo. +HJ+marzo+2020+web.pdf/bf0db075-be31-413f8496-e6d72ec72bf9.

[44] Moreno-Correa, S. M, "La innovación educativa en los tiempos del Coronavirus," [Educational innovation in the times of the Coronavirus], Salutem Scientia Spiritus, vol. 6, no. 1, pp. 14-26, 2020. https://revistas.javerianacali.edu.co/index.php/salute mscientiaspiritus/article/view/2290/2863.

[45] Cervantes Holguín, E., \& Gutiérrez Sandoval, P. R, "Resistir la COVID-19. Intersecciones en la 
Educación de Ciudad Juárez,” [Resist COVID-19. Intersections in the Education of Ciudad Juárez], México. Revista Internacional de Educación para la Justicia Social, vol. 9, no. 3e, 7-23, 2020. DOI: 10.15366/riejs2020.9.3.001.

[46] Mantilla, J, "Atropellos a la autonomía de los docentes: Desde la abolición de la tarima hasta la extorsión de profesores," [Violations of the autonomy of teachers: From the abolition of the stage to the extortion of teachers], Via Inveniendi Et Iudicandi, 2015. DOI: 10.15332/s1909-0528.2015.0001.06.

[47] Hurtado García, A, “Yo no soy maniático, ¡qué va!,” [I'm not a maniac, what's up!], El Tiempo, Sección Debes leer.2013.

[48] Hurtado García A, "La eficiencia del derecho a la educación," [The efficiency of the right to education], El Tiempo, Sección Debes leer.2014.
[49] Cajiao, F, "No hay mal que por bien no venga," [Every cloud has a silver lining], El Tiempo. Sección Debes leer. 2013.

[50] Cabeza, L., Zapata, A., \& Lombana, J, “Crisis de la profesión docente en Colombia: percepciones de aspirantes a otras profesiones," [Crisis of the teaching profession in Colombia: perceptions of applicants to other professions], Educación y Educadores, vol. 21, no. 1,51-72, 2018. DOI: 10.5294/edu.2018.21.1.3.

[51] Rosas-Baños, M, "Percepción de profesores investigadores sobre políticas educativas neoliberales en México," [Perception of research professors on neoliberal educational policies in Mexico], Revista Electrónica En Educación Y Pedagogía, vol. 3, no. 5, 39-61, 2019.

DOI: 10.15658/rev.electron.educ.pedagog19.09030503. 